\title{
Speeches and Declarations: A War of Words
}

\author{
Antonio Reyes-Rodríguez \\ University of Illinois \\ reyesrod@uiuc.edu
}

\begin{abstract}
The use of language is always manipulated to convey a goal of the speaker in order to have an effect on the hearer. Symbolic power is always present in speech. Politicians understand and harness the power of words to explain or justify acts in order to encourage, perhaps even force, people to support them, even if this support implies a risk to their lives. Following Bourdieu's (2001), Elster's $(1986,1994)$ and van Dijk's $(1993,1997 a, 1997 b, 2005)$ ideas, in particular, amongst others', this paper analyzes the speeches and declarations of George W. Bush, President of the United States, from September 11, 2001 leading up to the 2003 attack on Iraq, in an attempt to decode the underlying intentions of the messages and strategies which he has used to justify military action, in what he and his administration call 'the war on terrorism'. This paper focuses on the linguistic representations of war and their implications (van Dijk, 2005), on the way in which war is linguistically and rhetorically constructed, particularly in the period of build-up to action. This study will propose a theoretical model of the chronological discursive phases of development of a rhetoric of war, culminating in military action with general public support domestically. Finally, I would like to introduce the term 'ideologically suggestive co-placement' as a linguistic power tactic to link factually unrelated objects (persons, nations, events, concepts) by presenting them within a simple clause or sentence, to intentionally create a link between these objects, between their connotations in the listener's mind, simply by their simultaneous mention. This term is presented as a new tool for future discourse analysis studies.
\end{abstract}




\section{Introduction}

The September 11 attacks on the United States became incorporated into the development of a series of overseas military actions on the part of the U.S. administration, with the stated purpose of fighting terrorism in the world. The macro-structures have shaped the micro-structures (van Dijk, 1997a, 1997b). The New World Order (NWO) (Lazar and Lazar, 2004) dictates a new way to perceive reality. This change reflects the adaptation of new socio-semantic changes (Fairclough, 2002). At the present time, the U.S. armed forces are said to have ended the war in Iraq, and that this victory is part of the War on Terrorism campaign. These separate events have been linked and justified by the Bush administration, leading American public opinion to strongly support to U.S. abroad. Through an analysis of speeches and declarations made by President Bush since September 11, 2001, we can define a discursive pattern in which the attacks on the U.S. were harnessed to further the U.S. administration's discourse regarding Iraq, and other countries said to "harbor terrorists". We see that "politics is essentially a linguistic activity", an activity in which language is employed to inform others about political issues and persuade them to adopt courses of action with regards to these issues (Geis, 1987).

\section{Model of Rhetorical construction of War}

The following scheme will be derived from the discursive progression seen in the speeches and declarations of U.S. leaders in the build-up to the Gulf War, the war in Afghanistan, and, in particular, the war in Iraq:

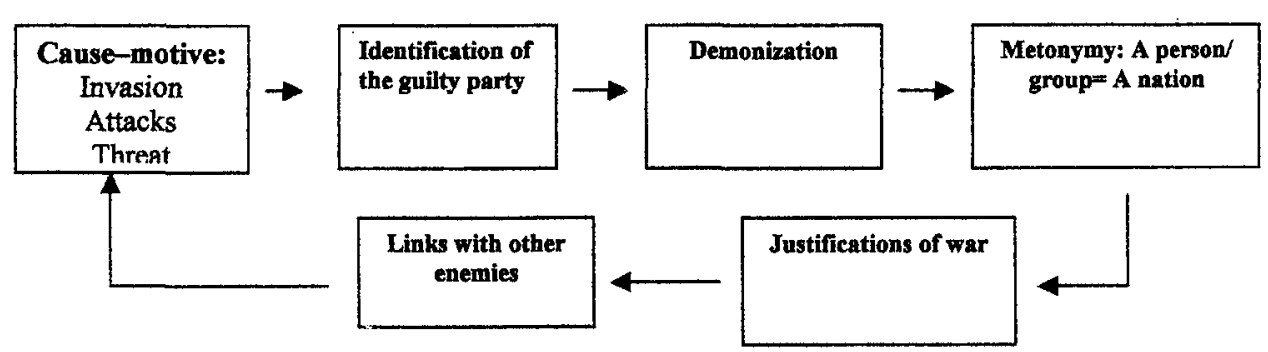

This model is presented as a basis for discussion of how power becomes consolidated through discourse and how ideologies achieve a "real materiality in the linguistic sign" (Demirovic, 1992:38). On an academic level, it provides a combination of analytical approaches, drawing on consideration of discourse, syntax, grammar, and culture in an attempt to contribute to the development of sociolinguistic theory. The perspective of Critical Discourse Analysis will provide useful tools to analyze the data. Within that framework, language is conceptualized as a form of social practice (see Fairclough 1989, 1995; Van Dijk, 1993). In the following pages I prove how Bush's speeches define the 
different phases of the mentioned model.

\section{Cause/Motive}

A succession of events, and their discursive presentation, entails a cause or motive identified (by the discourse-creators) as having started its development. Looking at recent previous military actions in which U.S. forces have been involved, hindsight has given us a clearer view of certain departure points, which were always present. This paper considers the escalation of U.S. military action, as presented in U.S. presidents' discourse, in the related events of the Gulf War, the most recent war in Afghanistan, and the war in Iraq. The Iraqi invasion of Kuwait set off a series of events that culminated in the Gulf War in 1991. The 2001 attacks on New York and Washington, D.C. can also be analyzed as having set off the development of a series of events through the war in Afghanistan to that, just months later, in Iraq.

Analysis of the interpretation and presentation of these events by the mass media and Bush Administrations is essential to an understanding of the build-up of argument and metaphor that soon came to make sense to U.S. public opinion. Once the public had approved and incorporated the metaphor, action could be taken and justified.

Elster's work on "Rationality, Emotions, and Social Norms" (1994) provides useful insights here. Elster discusses how social norms can adjust emotions to fit a rational framework and, likewise, how social norms can be constructed and imposed through appeal to emotions, under the guise of rationality, by political leaders. Politicians all over the world have tried to study and implement the steps to make emotions seem rational and decisions logical, and inevitable. On the basis of rational choice theory, governments can work with social norms to make any proposed choice seem rational (therefore logical), efficient, and, hence, the right thing to do.

On emotions Elster (1994) affirms the following:

...a crucial fact about the emotions is that they have the capacity to alter and distort the cognitive appraisal that triggered them in the first place. The object of an emotion is the emotionally distorted picture of its cause. This feedback from emotions is a key to the dynamics of the emotions (1994: 27).

We see the interaction of emotions and logic at work in the United States since September 11,2001 , as the terrorist attacks provoked very strong emotions on the part of the American populace. The current president, George W. Bush, developed a strategy to rationalize and instrumentalize these strong emotions in order to make citizens incorporate the logic of the 'war on terrorism' and support the attacks first on Afghanistan and later Iraq. In other words, the social norm of being at war was presented and imbued into the psyche of the American populace as 'common sense'.

Bush's first speech on September 11, 2001 defined the attacks as 'an Act of War", in 
an emotional, knee-jerk type of reaction. A more rational response might perhaps have been to look for the reasons and causes of these attacks, to collect and disseminate thorough and accurate information on the situation, prior to deciding a course of action. However, Bush immediately led public opinion to an idea of revenge against terrorists, motivating an ultra-patriotism on the part of U.S. citizens which would prevent them from questioning any kind of resolution coming from the administration, thereby consolidating his power and position.

In Bush's words, the appeal to emotion can be seen in the following declarations:

Today, our fellow citizens, our way of life, our very freedom came under attack in a series of deliberate and deadly terrorist attacks (Bush, "An Act of War", Address to the Nation, Sept. 11, 2001).

The relationship of solidarity with the public is manifested with the use of the possessive "our", which refers both to the administration and the general public. Bush here jumps immediately, without explicitly stating so, from the attack on the twin towers and Pentagon to an attack on the most precious value of humankind, and of Americans in particular, 'freedom'. He furthermore defines American society, 'our way of life", as embodying freedom. In the same stroke, the modifiers that accompany the noun: 'attacks", 'deliberate", 'deadly", and 'terrorist' initiate a process of (following foucauldian concepts) division (establishing an inclusive 'us' and an exclusive 'them') (Foucault, 1971) and rejection (evocation of an imagery dimension related to the ideology of consensus plus prejudices to portray the excluded as mad), as described by Martín Rojo (1995: 50). This binary conceptualization (Chilton, 2004) stirs and defines emotions. An emotion is being rationalized in order to set up a social norm which will readily be incorporated.

America was targeted for attack because we are the brightest beacon for freedom and opportunity in the world, and no one will keep that light from shining" (Bush, "An Act of War," Address to the Nation, Sept. 11, 2001).

With the cause stated by the adverbial clause, the president pre-empted a series of potentially uncomfortable questions regarding possible motivations for the attacks, such as U.S. policies abroad, and why the U.S., and not other countries, had been targeted. The president makes rational a conception that is a priori irrational, that the U.S. has been attacked because 'we' have freedom, as in the following:

Today our nation saw evil - the very worst of human nature - and we responded with the best of America and our friends and allies join with all those who want peace and security in the world. And we stand together to win the war against terrorism... This is a day when all Americans, from every walk of life, unite in our resolve for justice and peace. America has stood down enemies before and we will do so this time (Bush, "An Act of War," Address to the Nation, Sept. 11, 2001). 
Once the ideas of division and rejection have been mapped out, the next step is to win (without mentioning the fight) the 'war against terrorism'. It is worthwhile to mention another attempt to rationalize what in principle seems irrational: we will start a war because we want 'peace'. Furthermore, for a war to occur, an official declaration of war on a specific country or land needs to be made, whereby enemies must be specifically defined and concretized.

Without knowing the responsible party for the attacks, Bush was already pushing the idea of defending 'ourselves', of going to war, and winning this possible war. An enemy was created in order for it to be, apparently, fought and defeated. The metaphor, as defined by Lakoff and Johnson (2003), is a conceptual system in which one kind of thing is understood and experienced in terms of another. In this case, the relatively diffuse chaos of terrorism is conceived of, metaphorically, as a war and, as Lakoff and Johnson (2003) argue, the speaker discourse involves attacking, counter-attacking, defense, etc. Only, in this case, the war metaphor was used to set the stage for actual war.

Finally, it was stated that, in order to defeat this enemy and win this war, Americans must prevail united. In making this statement, Bush was establishing that support for this war would come to be the social norm, as it is made to appear to be 'common sense'.

The following excerpts reveal how Bush went on to extend the common 'we' to include other countries, in order to legitimize his stance:

Tonight we are a country awakened to danger and called to defend freedom. Our grief has turned to anger, and anger to resolution. Whether we bring our enemies to justice, or bring justice to our enemies, justice will be done (Bush, Address to Congress, Sept. 20, 2001).

Due to allocations in the sentence (Fairclough 2003) the semantic relationship between 'danger' and 'freedom' is stated. The chiasmic structure emphasizes the meaning of the word 'justice' repeated three times in the sentence and part of the above mentioned chiasmus.

Nor will we forget the citizens of $\mathbf{8 0}$ other nations who died with our own. Dozens of Pakistanis. More than 130 Israelis. More than 250 citizens of India. Men and women from El Salvador, Iran, Mexico and Japan. And hundreds of British citizens (Bush, Address to Congress, Sept. 20, 2001).

His citing of the specific numbers of victims (1) awakens the emotions of the public, (2) makes the proposed war a global war and (3) presents a knowledgeable and informed president (the 'number game': van Dijk, 2005). He indicates that it was not only the U.S. which was attacked and not only is the U.S. which is in 'danger'. It is not only an appeal for allies but also a reinforcement of the rejection of the 'enemies', of the 'them', who should also be hated by all the mentioned nations. It is interesting to note the inconsistency between the citing of a concrete number of people who died in the September 11 attacks, while the number of possible or actual casualties in the war remained unstated. This can be seen as a ploy to avoid a possible emotion of guilt on the part of citizens who had been led 
to support military action.

On September the eleventh, enemies of freedom committed an act of war against our country. Americans have known wars, but for the past 136 years, they have been wars on foreign soil, except for one Sunday in 1941 ... freedom itself is under attack (Bush, Address to Congress, Sept. 20, 2001).

The emotional framework is again developed. 'Freedom' is one of the most representative values in the U.S. Constitution, the most sacred of U.S. legal-political documents, and it now is under attack. In these metaphors, we find embedded a series of abstractions which are presented as concrete entities: 'the enemy' (which in fact was not clearly identified, in national terms) and 'freedom' (which is a concept, rather than a physical entity, against which an act of war, a physical action, cannot be committed).

In relation to Iraq, the following was the stated cause:

In 1991, Security Council Resolution 688 demanded that the Iraqi regime cease at once the repression of its own people, including the systematic repression of minorities, which the council said threatened international peace and security in the region. This demand goes ignored.

Last year the U.N. Commission on Human Rights found that Iraq continues to commit extremely grave violations of human rights and that the regime's repression is all-pervasive. Tens of thousands of political opponents and ordinary citizens have been subjected to arbitrary arrest and imprisonment; summary execution; and torture by beating and burning, electric shock, starvation, mutilation and rape. Wives are tortured in front of their husbands, children in the presence of their parents, and all of these horrors concealed from the world by the apparatus of a totalitarian state (Bush, Speech to the U.N. 9-12-02).

The conduct of the Iraqi regime is a threat to the authority of the United Nations and a threat to peace. Iraq has answered a decade of U.N. demands with a decade of defiance. All the world now faces a test, and the United Nations a difficult and defining moment. Are Security Council resolutions to be honored and enforced, or cast aside without consequence? (Bush, Speech to the U.N. 9-12-02).

As the fragments above suggest, "evil' attributions of an 'evil' past and the idea of threat stand as the motives for a war in the case of Iraq.

\section{Identification of the guilty party}

Once public opinion was touched emotionally, the next goal in President Bush's discourse was to identify the party responsible for these acts. We can notice that in the Address to the Nation on September 11, Bush was already explaining why the U.S. was attacked, but it was not until his September 20th Address to Congress that he explained who was responsible for these acts. This is the identification: 
Americans have many questions tonight. Americans are asking: Who attacked our country? The evidence we have gathered all points to a collection of loosely affiliated terrorist organizations known as al-Qaeda (Bush, Address to Congress, Sept. 20, 2001).

Americans are asking: Why do they hate us? They hate what we see right here in this chamber, a democratically elected government. Their leaders are self-appointed. They hate our freedoms, our freedom of religion, our freedom of speech, our freedom to vote and assemble and disagree with each other (Bush, Address to Congress, Sept. 20, 2001).

In order to maintain the audience's global vision without reference to the enemy side's stated reasons for these terrorist acts, Bush is presenting that it is known why the U.S. was attacked, but in his words. Again, the irrational (that is, statements backed by concepts rather than facts) was made to seem rational through the creation of an emotion that was generalized. To paraphrase the image communicated: 'They basically hate the U.S. because we have democracy'. It is interesting to wonder how this explanation could seem sufficient to the audience, as it might also be acknowledged (but is not) that the U.S. is not the only democratic country in the world.

As Martin Rojo (1995) points out, the very style of this type of speech lends itself readily to simplistic retransmission of single quotes as information itself. Such simplistic and abstract formulations are easily made directly into headlines and sound-bytes. As she explains, "these words seemed to constitute in themselves the information". (1995, p55) In the case of the conflict with Iraq:

We know that Saddam Hussein pursued weapons of mass murder even when inspectors were in his country (Bush, Speech to the U.N. 9-12-02).

As a former chief weapons inspector for the U.N. has said, "The fundamental problem with Iraq remains the nature of the regime itself: Saddam Hussein is a homicidal dictator who is addicted to weapons of mass destruction (Bush, Speech to America 10-07-02).

It is interesting to note how Bush, at this stage, identifies and defines Hussein as 'a homicidal dictator who is addicted to weapons of mass destruction", when later we will see that attribution of this quality will be extended to the whole of Iraq. The discourse at that point will shift to a focus on 'Iraq", indicating, as in Lakoff's metaphor (1991), the association of a person with a nation.

\section{Demonization of the enemy}

Once the enemy is defined, however vaguely, the next step in the construction of a discourse of war is to define the degree of 'evil', in U.S. Republican Party terminology, of this enemy. This brings us to the phase of demonization. In doing so, Bush and his administration know that the image which they create of the enemy depends on the 
linguistic choices which they make. Once again, language will be implemented to create an 'evil' image of the enemy, of the enemy as Evil itself. The administration knows, after previous use of this very term by former Republican President Ronald Reagan in referring to the 'Evil Empire' of the Soviet Union, that the more evil the representation of the enemy, the more support can be gained from the public. Such villification is seen in the following speech excerpt:

They are the same murderers indicted for bombing American embassies in Tanzania and Kenya and responsible for the bombing of the USS Cole...Al-Qaeda is to terror what the mafia is to crime. But its goal is not making money; its goal is remaking the world and imposing its radical beliefs on people everywhere (Bush, Address to Congress, Sept. 20, 2001).

The process of demonization is built into the discourse in words such as murders, terror, mafia, crime, and imposing radicals. We see how every piece of discourse is a representation, a re-presentation in the French sense, of reality, an interpretation.

The terrorists' directive commands them to kill Christians and Jews, to kill all Americans, and make no distinctions among military and civilians, including women and children (Bush, Address to Congress, Sept. 20, 2001).

Here we have a statement with a very simple message. Bush is essentially saying that the terrorists make no distinctions in their goals, 'they kill everybody'. Yet, this 'everybody' was broken down in his specifically naming two religious particular groups, Americans, and civilians. The message is that terrorists are so evil that they do not make distinctions. The linguistic choice here, however, is imprecise and inconsistent as his groupings overlap, for example, women and children are also civilians. Is it to be understood by this, for instance, that the life of a civilian man is less important than that of a woman or child? The point of the discourse, however, is not analytical precision, but rather the conscious goal of moving the audience emotionally by emphasizing the death of innocent and maybe unprotected human beings.

The next step in the demonization, toward a general discourse of war, is to personify 'the enemy' by saying that the terrorists have a leader:

This group and its leader, a person named Osama bin Laden, are linked to many other organizations in different countries, including the Egyptian Islamic Jihad and the Islamic Movement of Uzbekistan (Bush, Address to Congress, Sept. 20, 2001).

The foucauldian concepts (1971) of division (establishing an inclusive 'we') and rejection (establishing an exclusive 'the terrorists') are again present in the following clear enumeration of the good 'we' do versus the bad 'they' do.

We value education; the terrorists do not believe women should be educated, or should have 
health care, or should leave their homes. We value the right to speak our minds; for the terrorists, free expression can be grounds for execution. We respect people of all faiths and welcome the free practice of religion; our enemy wants to dictate how to think and how to worship, even to their fellow Muslims. This enemy tries to hide behind a peaceful faith. But those who celebrate the murder of innocent men, women and children have no religion, have no conscience and have no mercy. We wage a war to save civilization itself (Bush, "Let's Roll" 11-08-01).

Closely related to the creation of the enemy by negative attributional properties, the processes of 'division and rejection' portray the undesirable enemy as morally distant as possible from 'us' in questions of conduct, behaviors, actions, etc. This alienation takes place not only by emphasizing the difference but often by attributing the worst possible behaviors (i.e. 'celebrate the murder of innocent men, women and children') to 'them'. 'Division and rejection' are common strategies for the creation of the enemy by means of parallel contrastive structures, the use of pronominal subjects 'we' and 'they', and the use of the appraisal system among others (Morgan, 1997; Caldas-Coulthard, 2003; ÍñigoMora, 2004)

Otherness is created by multiple alternation of verbal mental process carried out by confronted subjects: 'we' vs. 'the terrorists'. The word 'terrorists' alternates with 'enemy' as the subject of otherness, which makes their definitions interchangeable.

Bush's text shows the role of 'Judgment' (Thompson 2004:77) in describing actions performed by the subject 'we' and 'the terrorists' (they).

\begin{tabular}{|l|l|}
\hline \multicolumn{1}{|c|}{ We } & \multicolumn{1}{c|}{ the terrorists } \\
\hline -valueeducation & $\begin{array}{l}\text {-do not believe women should be educated, } \\
\text { or should have health care, or should leave } \\
\text { their homes }\end{array}$ \\
\hline -value the right to speak our minds & $\begin{array}{l}\text { - (For 'them') free expression can be } \\
\text { grounds for execution }\end{array}$ \\
\hline $\begin{array}{l}\text {-respect people of all faiths and welcome } \\
\text { the free practice of religion }\end{array}$ & $\begin{array}{l}\text {-want to dictate how to think and how to } \\
\text { worship, even to their fellow Muslims. } \\
\text {-tries to hide behind a peaceful faith. } \\
\text {-celebrate the murder of innocent men, } \\
\text { women and children }\end{array}$ \\
\hline -wage a war to save civilization itself & \\
\hline
\end{tabular}

The transitivity analysis of these sentences shows mostly mental processes (Thompson 2004). 


\begin{tabular}{|c|c|c|}
\hline$\frac{\text { Sensor }}{\text { (Subjects) }}$ & $\begin{array}{l}\text { Process: mental } \\
\text { value (emotion) } \\
\text { do not believe (cognitive) } \\
\text { respect (emotion) } \\
\text { want (desideration) }\end{array}$ & $\begin{array}{l}\text { Phenomenon } \\
\text { education } \\
\text { women should be educated or should have... } \\
\text { people of all faiths and welcome the free ... } \\
\text { to dictate how to think and how to worship... }\end{array}$ \\
\hline
\end{tabular}

The judgment is then based on a description of the way they think more than the actions they perform. Verbs of mental process present, in appraisal terms, an extreme subjectivism since concrete actions (material process) can be corroborated with reality, while beliefs and ways of thinking are questions of perspective (i.e. western). Bush has built a solid wall based on values that separate 'us' from 'them'. These ideas are expressed through repetitive structures full of parallelisms and highly semantically loaded words (from the perspective of western culture, i.e. freedom of expressions, respect to women, etc). The hearer of those accusations will likely feel repulsion for 'terrorists' and believe that they are really 'terrorists'. However none of those accusations can define a person as a terrorist; there is nothing in what they believe or do that can be used to define them as 'terrorist'. We only have material with which to call them antidemocratic, disrespectful, cold-hearted, discriminatory against women, etc.

Finally, the last sentence 'We wage a war to save civilization itself' is a hyperbolic manifestation that distorts reality and displays a 'big claim' that collaborates with this language of deception and manipulation (Galasinski 2000: 42).

It is interesting to note, in addition, the title of this speech, "Let's Roll," which has intense emotional connotations in itself for Americans. It conveys at the same time patriotism, heroism, courage, selflessness and danger, fear, uncertainty, risk to life, as it refers to the last words by cell phone of a passenger to his wife on the final downed plane of September 11, as he was said to have been going to stop the hijackers with a group of passengers. The phrase which has become universally known by Americans furthermore conveys, and even more significantly, the idea of action, self-defense, vengeance, fighting, and sacrifice, key concepts in the language of war. This sense of fear and threat to Americans' lives is then kept up in future speeches.

More than anything else, this separates us from the enemy we fight. We value every life. Our enemies value none, not even the innocent, not even their own (Bush: "9-11 Anniversary Speeches" 9-11-02).

The process of demonization, as the speech to the U.N. went on, became more intense and exaggerated, with the targeting of Saddam Hussein in the Operation named 'Free Iraq' by Bush and his administration:

Saddam Hussein attacked Iran in 1980 and Kuwait in 1990. He's fired ballistic missiles at Iran and Saudi Arabia, Bahrain and Israel. His regime once ordered the killing of every person between the ages of 15 and 70 in certain Kurdish villages in northern Iraq. He has gassed many Iranians and 40 Iraqi villages (Bush, Speech to the U.N. 9-12-02). 
...a murderous tyrant, who has already used chemical weapons to kill thousands of people. This same tyrant has tried to dominate the Middle East, has invaded and brutally occupied a small neighbor, has struck other nations without warning, and holds an unrelenting hostility towards the United States (Bush, Speech to America 10-07-02).

We know that the regime has produced thousands of tons of chemical agents, including mustard gas, sarin nerve gas, and VX nerve gas. Saddam Hussein also has experience in using chemical weapons. He has ordered chemical attacks on Iran, and on more than forty villages in his own country. These actions killed or injured at least 20,000 people, more than six times the number of people who died in the attacks of September 11 (Bush, Speech to America 10-07-02).

In this last text, it is interesting to observe the second term of comparison. In talking about Hussein's atrocities, Bush compares the number of people he killed with the number of people who died in the attacks of 9-11. A clear link between Hussein and the attacks on September 11 has never been shown, yet this association creates this implication for the audience. By repeating an apparent link between these factually unrelated concepts, the speaker leads the audience to familiarize itself with this association, and, therefore, take it as a norm. I would like to call this strategy, very often seen on the part of politicians, "ideologically suggestive co-placement". I. I would define this linguistic power tactic as occurring when two factually unrelated objects (persons, nations, events, concepts) are linked by being presented within a simple sentence. This can be used to intentionally create a link between these objects, between their connotations in the listener's mind, simply by their simultaneous mention. It is different form the Laclau and Mouffe's 'logic of equivalence' (1985) since there is not only an attempt to equalize but also to connect objects/persons in other possible semantic relations such as cause-consequence or doerreceiver, and to help the process of 'naturalization' of ideologies (Fairclough, 2002).

\section{Metonymy: A person/group $=$ A nation}

Having a personified enemy, Bush needed a place to locate 'them'. The connection comes in the following sentences:

There are thousands of these terrorists in more than 60 countries. They are recruited from their own nations and neighborhoods, and brought to camps in places like Afghanistan where they are trained in the tactics of terror. They are sent back to their homes or sent to hide in countries around the world to plot evil and destruction. The leadership of al-Qaeda has great influence in Afghanistan, and supports the Taliban regime in controlling most of that country. In Afghanistan, we see al-Qaeda's vision for the world (Bush, Address to Congress, Sept. 20, 2001).

We draw on Chilton and Lakoff's methaphor (1995) where 'A person/ a group = a nation'. 
The connection has been made in the above statement and now the words used to define the terrorist group, al-Qaeda, can be tied and extended to the Taliban Regime and the country of Afghanistan.

This extension is then taken a step further in the normalization of war for the American public. As would also be seen later with Saddam Hussein and Iraq, this war against evil is not only for 'our' own (that of citizens of the U.S.) or the rest of the world's safety, but also for that of the citizens of Afghanistan. Despite years of Taliban rule in this country, suddenly its people are defined by Bush at this point as suffering and in need of liberation. This process is one of the more impressive in the construction of a discourse of war. Following Elster's ideas (1986), we see how something apparently irrational, such as war in one's own country, is presented as beneficial (hence rational) for the people who live there. The idea that bombs will bring liberation was constructed as a social norm and a shared emotion.

Afghanistan's people have been brutalized, many are starving and many have fled. Women are not allowed to attend school. You can be jailed for owning a television. Religion can be practiced only as their leaders dictate. A man can be jailed in Afghanistan if his beard is not long enough (Bush, Address to Congress, Sept. 20, 2001).

Now we have all the elements of what Chilton and Lakoff (1995) called 'the fairy tale of the just war': the villain (the Taliban regime), the good guy (the U.S.), and the innocent victims to save from the evil villain (the Afghani people):

the oppressed people of Afghanistan will know the generosity of America and our allies. As we strike military targets, we will also drop food, medicine and supplies to the starving and suffering men and women and children of Afghanistan. The United States of America is a friend to the Afghan people, and we are the friends of almost a billion worldwide who practice the Islamic faith (Bush, Address to Congress, Sept. 20, 2001).

In the case of Iraq, the following fragment proves how Iraq becomes the subject of predicates, such as 'continues to shelter and support terrorist organizations' and 'attempted to assassinate the emir of Kuwait and a former American president':

One American pilot is among them. In 1991, the U. N. Security Council, through resolution 687 , demanded that Iraq renounced all involvement with terrorism and permit no terrorist organizations to operate in Iraq... It broke this promise. In violation of Security Council resolution 1373, Iraq continues to shelter and support terrorist organizations that direct violence against Iran, Israel and Western governments. Iraqi dissidents abroad are targeted for murder. In 1993, Iraq attempted to assassinate the emir of Kuwait and a former American president (Bush, Speech to the U.N. 9-12-02). 


\section{Justifications of war}

Once the demonization of the enemy has been completed and the target identified, the next step is the justification of military action against that enemy. As we have analyzed, the purpose of fighting these people is not only to fight the enemies of America or freedom, but also to save Afghanis from their compatriot 'murderers'.

The United States respects the people of Afghanistan. After all, we are currently its largest source of humanitarian aid, but we condemn the Taliban regime. It is not only repressing its own people, it is threatening people everywhere by sponsoring and sheltering and supplying terrorists. By aiding and abetting murder, the Taliban regime is committing murder (Bush, Address to Congress, Sept. 20, 2001).

Following this pronouncement, in an attempt to portray fairness, the administration communicates certain demands on the Taliban regime. In doing this, the administration will seem fair, good-hearted, cool-headed, and, most importantly, to provide choices; the U.S. government will give the Talibans a chance to avoid military conflict. Thus, the U.S. administration is fully transferring guilt to the Taliban regime: if they do not meet these demands, they will be the guilty party in this war. Let us look at the following:

And tonight, the United States of America makes the following demands on the Taliban: Deliver to United States authorities all the leaders of al-Qaeda who hide in your land.

Give the United States full access to terrorist training camps, so we can make sure they are no longer operating.

These demands are not open to negotiation or discussion. The Taliban must act and act immediately. They will hand over the terrorists, or they will share in their fate.

Our war on terror begins with al-Qaeda, but it does not end there. It will not end until every terrorist group of global reach has been found, stopped, and defeated (Bush, Address to Congress, Sept. 20, 2001).

Following these demands, Bush again works to demonize the enemy in order to reactivate citizen emotions and widen and deepen the rift of rejection. This is precisely what Elster underlines in his idea that: 'this feedback from emotions is a key to the dynamics of the emotions'. (1994: 27) Let us look at this, which Elster has called 'instrumental rational exploitation of a social norm' (Ibid), in the following:

These terrorists kill not merely to end lives, but to disrupt and end a way of life. With every atrocity, they hope that America grows fearful, retreating from the world and forsaking our friends. They stand against us, because we stand in their way (Bush, Address to Congress, Sept. 20, 2001).

In the following excerpt from the same speech, we can see a clear example of normalization. Bush is setting norms in order to legitimize war: 
Americans are asking: How will we fight and win this war? (Bush, Address to Congress, Sept. 20, 2001).

Referring to Elster (1994), a social norm consists of adjusting emotions to fit a rational framework; this social norm is constructed and imposed through appeal to emotions, under the guise of rationality. By saying that "Americans are asking", Bush is putting this question in every American's mouth; even if it did not occur to the audience previously, war now becomes a given. Continuing to create the public's views, Bush defines what Americans 'must' expect:

Americans should not expect one battle, but a lengthy campaign, unlike any other we have seen. It may include dramatic strikes, visible on television, and covert operations, secret even in success (Bush, Address to Congress, Sept. 20, 2001).

In the following fragment, Bush states a warning for the rest of the world wherein middle positions are not allowed. He thus creates an either-or constraint, using autonyms, as in: 'Either you are with us, or you are with the terrorists'. As Martín Rojo mentions, we can appreciate "the maintenance of the illocutionary force used by American diplomacy". (1995: 55):

And we will pursue nations that provide aid or safe haven to terrorism. Every nation, in every region, now has a decision to make. Either you are with us, or you are with the terrorists. From this day forward, any nation that continues to harbor or support terrorism will be regarded by the United States as a hostile regime (Bush, Address to Congress, Sept. 20, 2001).

The following is one of the clearest justifications for the war:

But the only way to defeat terrorism as a threat to our way of life is to stop it, eliminate it, and destroy it where it grows (Bush, Address to Congress, Sept. 20, 2001).

The war now becomes justified not only for the U.S., but as the 'world's fight'; the idea is to now create a social norm with international validity.

This is not, however, just America's fight. And what is at stake is not just America's freedom. This is the world's fight. This is civilization's fight. This is the fight of all who believe in progress and pluralism, tolerance and freedom (Bush, Address to Congress, Sept. 20, 2001).

This statement leaves no choice for any other country; to say that: 'This is the fight of all who believe in progress and pluralism, tolerance and freedom", is to say that those who do not fight do not believe in progress, pluralism, tolerance, or freedom. In other words, he is saying that, in this war, 'we' are not alone, other powerful countries are with the U.S., as in the following to the United Nations: 
They can be expected to use chemical, biological and nuclear weapons the moment they are capable of doing so. No hint of conscience would prevent it. This threat cannot be ignored. This threat cannot be appeased. Civilization itself, the civilization we share, is threatened. We act to defend ourselves and deliver our children from a future of fear (Bush, U.N. Address, 11-10-01).

The cause is thus logical and makes sense, since other 'civilized' nations, those who do believe in these principles, are on 'our' side. It is interesting to note in the following, however, that two of the countries mentioned in the following excerpt (hence deemed at the time to be one of 'us') did not ultimately support the U.S. war in Iraq, further underlining the unilateral and self-serving nature of Bush's 'we' construction:

Other close friends, including Canada, Australia, Germany and France, have pledged forces as the operation unfolds (Bush, "Freedom Will Prevail", 10-07-01).

The fact that powerful first world countries (of three different continents) support the U.S. implies that the U.S. made the right decision and the alliance is a 'strong' one.

In relation to Iraq, the war was justified in the following terms:

With every step the Iraqi regime takes toward gaining and deploying the most terrible weapons, our own options to confront that regime will narrow. And if an emboldened regime were to supply these weapons to terrorist allies, then the attacks of September the 11th would be a prelude to far greater horrors (Bush, Speech to the U.N. 9-12-02).

Again, a subtle 'ideological suggestive co-placement': talking about Iraq ('Iraqi regimen') Bush mentions the September 11, as we also observe in the next fragment.

The Iraqi regime has violated all of those obligations. It possesses and produces chemical and biological weapons. It is seeking nuclear weapons. It has given shelter and support to terrotism and practices terror against its own people.

We also must never forget the most vivid events of recent history. On September 11, 2001, America felt its vulnerability -- even to threats that gather on the other side of the earth. We resolved then, and we are resolved today, to confront every threat, from any source, that could bring sudden terror and suffering to America (Bush, Speech to America 10-07-02).

We now come to one of the more direct justifications for the war: it makes sense to stop Saddam, to go to war:

Some ask how urgent this danger is to America and the world. The danger is already significant, and it only grows worse with time. If we know Saddam Hussein has dangerous weapons today -- and we do -- does it make any sense for the world to wait to confront him as he grows even stronger and develops even more dangerous weapons? (Bush, SPEECH TO AMERICA 10-07-02). 
The call to emotion is again used by Bush as a strategy to give sense to his words and garner audience support, as we seen in the following:

And we know that after September 11, Saddam Hussein's regime gleefully celebrated the terrorist attacks on America. Iraq could decide on any given day to provide a biological or chemical weapon to a terrorist group or individual terrorists....

Alliances with terrorists could allow the Iraqi regime to attack America without leaving any fingerprints.

When I spoke to the Congress more than a year ago, I said that those who harbor terrorists are as guilty as the terrorists themselves. Saddam Hussein is harboring terrorists and the instruments of terror, the instruments of mass death and destruction. And he cannot be trusted. The risk is simply too great that he will use them, or provide them to a terror network (Bush, Speech to America 10-07-02).

Our first sentence shows again an 'ideologically suggestive co-placement': 'September 11' and 'Saddam Hussein' are together in the sentence separate by a comma.

Of particular interest in noting Bush's appeal to emotion over rationality is the following statement. Uncertainty as to the answer to the question of whether or not Saddam is close to developing a nuclear weapon, instead of prompting reevaluation and more careful decision-making, is used in a contrary manner to, rather, call for imminent action:

Many people have asked how close Saddam Hussein is to developing a nuclear weapon. We don't know exactly, and that is the problem (Bush, Speech to America 10-07-02).

As we saw with Afghanistan, the goal and justification for war is likewise to end the suffering of the people of Iraq:

The United States has no quarrel with the Iraqi people. They've suffered too long in silent captivity. Liberty for the Iraqi people is a great moral cause and a great strategic goal. People of Iraq deserve it (Bush, Speech to the U.N. 9-12-02).

If we fail to act in the face of danger, the people of Iraq will continue to live in brutal submission... (Bush, Speech to the U.N. 9-12-02).

And one of the advantages Iraqi people will have after the war is that they can join the list of democratic countries and improve their lives:

They can one day join a democratic Afghanistan and a democratic Palestine, inspiring reforms throughout the Muslim world (Bush, Speech to the U.N. 9-12-02).

The lives of Iraqi citizens would improve dramatically if Saddam Hussein were no longer in power, just as the lives of Afghanistan's citizens improved after the Taliban (Bush, Speech to the U.N. 9-12-02). 
As we saw with the war with Afghanistan, Bush is making a question into a fact, a social norm:

Since we all agree on this goal, the issue is: How can we best achieve it? (Bush, SPEECH TO AMERICA 10-07-02).

The question, however, remains unanswered, as Bush intended, as to who exactly agrees. Did he ask the opinion of citizens or is it already a given that 'we' all agree? That affirmation presents the war as a given necessity approved ('agreed') without elicitation by all U.S. citizens.

\subsection{Attribution of guilt}

The attribution of guilt occurs in the following fragment, wherein it is stated that it is the failure of the Taliban regime to fulfil the stated U.S. demands which makes them the guilty party in choosing the war, leaving the U.S. with no other choice than war:

More than two weeks ago, I gave Taliban leaders a series of clear and specific demands: Close terrorist training camps. Hand over leaders of the al-Qaida network, and return all foreign nationals, including American citizens unjustly detained in our country. None of these demands were met. And now, the Taliban will pay a price. By destroying camps and disrupting communications, we will make it more difficult for the terror network to train new recruits and coordinate their evil plans. Initially, the terrorists may burrow deeper into caves and other entrenched hiding places (Bush, "Freedom Will Prevail", 10-07-01).

Despite the declared intentions to go to war, Bush nevertheless reiterates the lack of American culpability:

We're a peaceful nation (Bush, "Freedom Will Prevail", 10-07-01).

The U.S. did not want this war, but is there a better cause for which to fight than Freedom?

We did not ask for this mission, but we will fulfill it. The name of today's military operation is Enduring Freedom (Bush, "Freedom Will Prevail", 10-07-01).

Again, Bush is trying to socialize the American people and the international community to the norm of war with the creation of a norm based on both a contradictory (hence imposed) obligation:

We have no other choice, because there is no other peace... We did not ask for this mission, yet there is honor in history's call (Bush, U.N. Address, 11-10-01).

In the case of Iraq, as with the Taliban, we also see that it was Iraq's choice to avoid the 
war, but they did not want peace:

If the Iraqi regime wishes peace, it will immediately and unconditionally foreswear, disclose, and remove or destroy all weapons of mass destruction, long-range missiles and all related material.

If the Iraqi regime wishes peace, it will immediately end all support for terrorism and act to suppress it, as all states are required to do by U.N. Security Council resolutions.

If the Iraqi regime wishes peace, it will cease persecution of its civilian population, including Shi'a, Sunnis, Kurds, Turkomen, and others - again, as required by Security Council resolutions.

If the Iraqi regime wishes peace, it will immediately end all illicit trade outside the oil-forfood program. It will accept U.N. administration of funds from that program to ensure that the money is used fairly and promptly, for the benefit of the Iraqi people.

If all these steps are taken, it will signal a new openness and accountability in Iraq. And it could open the prospect of the United Nations helping to build a government that represents all Iraqis - a government based on respect for human rights, economic liberty and internationally supervised elections (Bush, SPEECH TO THE U.N. 9-12-02).

\subsection{Religious support}

At this point, I would like to mention that an indirect way (common examples of which are found throughout history) of justifying war is to say that God is on 'our' (in this case, the U.S'.s) side. Such mentions are presented on many occasions in Bush's speeches. This reveals another paradox, another contradiction: a principle argument which Bush uses to demonize Osama is that he is a religious fanatic,

The terrorists call their cause holy, yet they fund it with drug dealing. They encourage murder and suicide in the name of a great faith that forbids both. They dare to ask God's blessing as they set out to kill innocent men, women and children. But the God of Isaac and Ismail would never answer such a prayer (Bush, U.N. Address, 11-10-01).

Bush also claims to be acting in the name of God and asking God for help in this conflict. Here are a number of examples:

Tonight I ask for your prayers for all those who grieve, our security has been threatened. And I pray that they will be comforted by a power for the children spoken through the ages, in Psalm 23. 'Even though I walk through the valley of the shadow of death, I fear no evil, for you are with me (Bush, "AN ACT OF WAR" SEPT. 11, ADDRESS TO THE NATION).

Fellow citizens, we will meet violence with patient justice assured of the rightness of our cause, and confident of the victories to come. In all that lies before us, may God grant us wisdom, and may He watch over the United States of America. Thank you (Bush, Address to Congress, Sept. 20, 2001). 
May God continue to bless America (Bush, "Freedom Will Prevail", 10-07-01).

And in the case of Bin Laden we find striking similarities:

God has blessed a group of vanguard Muslims, the forefront of Islam, to destroy America. May God bless them and allot them a supreme place in heaven, for He is the only one capable and entitled to do so. When those have stood in defense of their weak children, their brothers and sisters in Palestine and other Muslim nations, the whole world went into an uproar, the infidels followed by the hypocrites (Bin Laden, "No Peace for America", 10-07-01).

God is the Greatest and glory be to Islam (Bin Laden, "No Peace for America", 10-07-01).

This religious mention is also present in the Iraq war,

May He guide us now, and may God continue to bless the United States of America (Bush, STATE OF THE UNION ADDRESS 01-28-03).

\section{Links with other enemies}

Once the war is over, the reasons why the war was started (to hunt Osama Bin Laden in Afghanistan and to disarm Hussein in Iraq) are ignored and deviated. If the U.S. administration thinks it necessary to start another conflict, the whole process can start again by adding a link to further enemies. We saw this happen following the conclusion of the conflict with Afghanistan. On January 29, 2002, Bush linked this previous war in Afghanistan with the next goal by saying that the threat is still alive. Although he mentions several possible enemies, he dedicates particular explanation to Iraq. Here we see the precise point of departure from which to perpetuate the cycle:

Our second goal is to prevent regimes... these tegimes have been pretty quiet since September 11...Iraq continues to flaunt its hostility toward America and to support terror (Bush, State of the Union Address, 1-29-02).

And al Qaida terrorists escaped from Afghanistan and are known to be in Iraq (Bush, SPEECH TO THE U.N. 9-12-02).

We know that Iraq and the al Qaeda terrorist network share a common enemy -- the United States of America. We know that Iraq and al Qaeda have had high-level contacts that go back a decade. Some al Qaeda leaders who fled Afghanistan went to Iraq (Bush, SPEECH TO AMERICA 10-07-02). 


\section{Conclusion}

We have seen in this essay that the discourse of war can be seen to have a specific course of development through various specific phases of linguistic choice. A specific ideology is set out according to precise linguistic choices made at each stage which are designed to convey an intentional message toward a single goal. I have shown in this essay that the framework set out at the beginning applies, not only in an isolated event, but across several bellicose situations. Furthermore, these stages are seen to occur in a specific chronological order in Bush's speeches. While there is overlap between strategies in the different stages, this can be seen as a result of reiteration of previous strategies throughout subsequent stages in an effort to reinforce the ideology presented as a whole.

We have seen that in instances when the government's actions are called into question, as bordering on the edge between rationality and irrationality, Bush reminds the people of 'September $11^{\text {th' }}$ to stir the emotions of doubtful citizens, as well as calling into play the social norm of patriotism, by which dissenters are sanctioned by a supposed majority and shamed into consent. With this simplistic rationalization, Bush's approach appears rational, clear, and supported by public opinion. However, Bush has actually played with emotions in order to prove his own interests as being rational for others. This is precisely what Elster underlines in his idea that: "this feedback from emotions is a key to the dynamics of the emotions'. (1994: 27) This is a clear indication of what Elster called 'instrumental rational exploitation of a social norm' (Ibid).

Finally, we uncovered a phenomenon which has not been previously addressed in linguistics, wherein the power of suggestion is achieved by the simple statement of unrelated objects within the same sentence. I termed this, for want of a better description, 'ideologically suggestive co-placement' of objects in close proximity within a text. Along the lines of Bourdieu's treatment of symbolic structure, we could see that knowledge was being created through the communication of a link in a grammatically structured relation by an authority figure. In a fast-paced world of sound bytes and headlines as the often sole sources of information for many persons, this single-sentence structure becomes a very powerful communication strategy for the politician.

\section{Notes}

1. Drawing from Eagleton's (1991), we consider that ideology "has to do with legitimating the power of a dominant social group". Eagleton sets out six strategies which a dominant power may use to legitimate itself: (1) promoting beliefs and values congenial to it; (2) naturalizing and (3) universalizing such beliefs so as to render them self-evident and apparently inevitable; (4) denigrating ideas which might challenge it; (5) excluding rival forms of thought; and (6) obscuring social reality in ways convenient to itself. (Eagleton, 1991: 5) 


\section{Text Materials}

Bush speeches and declarations - Text of speeches to the nation and to Congress since September 11, 2001, on the website http://www.newwartimes.com/speeches.html

-e.g. "An Act of War" speeches on Sept. 11 and Sept. 20, 2001

\section{References}

Bourdieu, Pierre (2001): Language \& Symbolic Power, Cambridge, MA: Harvard University Press, $6^{\text {th }}$ edition, translation by G. Raymond and M. Adamson.

Caldas-Coulthard, Carmen R (2003): "Cross-cultural representation of 'Otherness' in Media

Discourse". In G. Weiss and R. Wodak, eds., Critical Discourse Analysis: Theory and Interdisciplinarity. New York: Palgrave Macmillan.

Chilton, Paul (2004): Analysing Political Discourse: Theory and Practice. London: Routledge. Chilton, Paul and George Lakoff (1995): "Foreign Policy by Metaphor". In C. Schäffner and A.

Wenden (eds). Language and Peace. Australia: Harwood Academic Publishers.

Demirovic, A (1992): Hegemony and State. Munster, Westfali, Dampfboot Verlag.

Eagleton, T (1991): Ideology: an introduction. London: Verso.

Elster, J (1986): Rational Choice. Washington Square, NY: New York University Press.

. (1994): "Rationality, emotions, and social norms". Synthese 98: 21-49.

Fairclough, Norman (1989): Language and Power. London: Longman.

. (2002): "Register, Power, and Socio-semantic Change". In M. Toolan, ed., Critical

Discourse Analysis. London: Rontledge.

(2003): Analyzing Discourse. London: Routledge.

Foucault, Michel (1971): L'ordre du discours. Paris: Gallimard.

Galasinski, D (2000): The Language of Deception: A Discourse Analytical Study. Thousand Oaks: Sage.

Geis, M.L (1987): The Language of Politics. New York: Springer-Verlag.

. (1995): Critical Discourse Analysis. The Critical Study of Language. London: Longman.

İ̃igo-Mora, I (2004): "On the use of the personal pronoun we in communities". Journal of Language and Politics 3(1): 27-52.

Laclau, E and Mouffe, C (1985): Hegemony and Socialist Strategy. London: Verso.

Lakoff, G (1991): "Metaphor and war: The metaphor system used to justify war in the Gulf". Peace Research 23: 25-32.

Lakoff, G. and M., Johnson (2003): Metaphors we Live by. Chicago: University of Chicago Press.

Lazar, Annita and Michelle M. Lazar (2004): "The discourse of the New World Order: 'OutCasting' the Double Face of Threat". Discourse \& Society 15: 223-242.

Martín Rojo, Luisa (1995): "Division and rejection: from the personification of the Gulf conflict to the demonization of Saddam Hussein". Discourse \& Society, 6(1): 49-80.

Morgan, P. (1997): "Self-presentation in a speech of Newt Gingrigh". Pragmatics 7: 275-308.

Thompson, Geoff (2004): Introducing Formal Grammar. $2^{\text {nd }}$ ed. London: Arnold.

Titscher, Stefan, Michael Meyer, Ruth Wodak and Eva Vetter (2000): Methods of Text and Discourse Analysis. London: Sage publications.

Van Dijk, Teun (1993): "Principles of Critical Discourse Analysis". Discourse \& Society 4(2): 249-283. 
. (1997a): "The study of discourse". In T.A. van Dijk, ed., Discourse as Structure and Process. London: Sage. Vol. 1: 1-34.

. (1997b): "Discourse as interaction in society". In T.A. van Dijk, ed., Discourse as Structure and Process. London: Sage. Vol. 2: 1-37.

. (2005): "War rhetoric of a little ally. Political implicatures and Aznar's legitimatization of the war in Iraq". Journal of Language and Politics 4(1): 65-92. 